\title{
The presence of the Problem-based Learning syntax in junior high school biology textbooks
}

\author{
Nurdiyah Lestari a,1,*, St. Muthmainnah Yusuf a,2, K. Ivo Basri a,3 , S. Suciati b,4, Mohammad Masykurı c,s \\ a Biologi Education Study Program, Faculty of Teacher Training and Education, Universitas Muhammadiyah Kupang, Jl. KH. Ahmad Dahlan, \\ Kupang, East Nusa Tenggara 85111, Indonesia \\ b Science Education Study Program, Faculty of Teacher Training and Education, Universitas Sebelas Maret Surakarta, Jl,Ir. Sutami No. 36A \\ Kentingan Surakarta, Central Java 75126, Indonesia \\ CPostgraduate Universitas Sebelas Maret Surakarta, Jl. Ir. Sutami No.36 A Kentingan Surakarta, Central Java 75126, Indonesia \\ ${ }^{1}$ nurdiyah.72@gmail.com *; 2 smuthmainnah@yahoo.co.id; ${ }^{3}$ ivobasrik@yahoo.co.id, ${ }^{4}$ suciatisudarisman@yahoo.com, ${ }^{5}$ mmasykuri@yahoo.com \\ ${ }^{*}$ Corresponding author
}

\begin{tabular}{|c|c|}
\hline ARTICLE INFO & ABSTRACT \\
\hline \multirow[t]{2}{*}{$\begin{array}{l}\text { Article history } \\
\text { Received January 23, } 2020 \\
\text { Revised February 20, } 2020 \\
\text { Accepted February 29, } 2020 \\
\text { Published March 31, } 2020 \\
\text { Keywords } \\
\text { Biology textbook } \\
\text { Learning syntax } \\
\text { Problem-based learning }\end{array}$} & $\begin{array}{l}\text { Learning resources and learning models are the two main components that determine } \\
\text { learning success. Of the many learning models, Problem-based Learning (PBL) is one } \\
\text { of the most recommended in biology learning. The purpose of this content analysis was } \\
\text { to identify the emergence of PBL syntax in junior high school biology textbooks. The } \\
\text { population in this study were all biology textbooks for the VII graders, while the sample } \\
\text { was three biology textbooks that are often used by VII graders in Surakarta. As the } \\
\text { results, the averages of each PBL step emerged in the textbooks analyzed i.e. problem- } \\
\text { oriented activity, organizing to collect data, assisting independent investigations, } \\
\text { artifacts presentations, and analyzed/evaluated the process of overcoming the problem } \\
\text { were } 17 \%, 47 \%, 23 \%, 2 \% \text {, and } 11 \% \text {, respectively. Thus, it can be concluded that the } \\
\text { biology textbooks analyzed have applied PBL learning models, yet the proportion } \\
\text { between steps is not balanced. }\end{array}$ \\
\hline & $\begin{array}{l}\text { Copyright } \odot \text { 2020, Lestari et al } \\
\text { This is an open access article under the CC-BY-SA license }\end{array}$ \\
\hline \multicolumn{2}{|c|}{$\begin{array}{l}\text { Lestari, N., Yusuf, S. M., Basri, K. I., Suciati, S., \& Masykuri, M. (2020). The presence of the Problem-based } \\
\text { Learning syntax in junior high school biology textbooks. JPBI (Jurnal Pendidikan Biologi Indonesia), 6(1), 9-14. doi: } \\
\text { https://doi.org/10.22219/jpbi.v6i1.11096 }\end{array}$} \\
\hline
\end{tabular}

\section{INTRODUCTION}

Textbooks are included in the main learning component that affect learning outcomes (Piper, Simmons Zuilkowski, Dubeck, Jepkemei, \& King, 2018; Prasetya, 2018). In a variety of learning, the presence of the textbook has a vital role during the learning process (Behnke, 2018; Menkabu \& Harwood, 2014; Wen-Cheng, Chien-Hung, \& Chung-Chieh, 2011). The reason is, through the textbook, students will get a variety of information regarding knowledge discussed in learning (Ham \& Heinze, 2018). Even, its use is still carried out until in the current digital era (Knight, 2015; Lau et al., 2018).

Responding to the importance of the textbook in the learning process, various studies were conducted. Several studies in various countries have been able to develop innovative textbooks, such as in Turkey (Dolmacı \& Ertal, 2016; Simsek, 2014) until Indonesia (Hendikawati \& Arini, 2016; Karim, 2015; Mukundan, Nimehchisalem, \& Hajimohammadi, 2011; Seftari, Milama, \& Saridewi, 2018). Another paper attempts to review the process of developing textbooks ( $\mathrm{Gu}, \mathrm{Wu}, \& \mathrm{Xu}, 2015)$. In addition, there are studies that analyze 
the role of textbooks in increasing literacy and numeracy (Piper et al., 2018). There is also study that analyze student satisfaction with the textbooks they read (Amiryousefi \& Zarei, 2011; Cimer \& Coskun, 2018), and evaluating the pedagogical value of books from students and teachers perspectives (Mohammadi \& Abdi, 2014).

Regarding its use, one of the subjects that almost always uses textbooks is Biology (Pop-Pacurar \& Ciascai, 2010). As a important note, the existence of the textbook is expected to support the characteristics of biology learning. Biology learning should be carried out by giving students the opportunity to find or implement their own ideas. For students, learning must shift from "being told" to "actively finding out". Students are also positioned as discoverers of knowledge not just users or memorizers of knowledge (Jiun \& Nurzatulshima, 2014; Pedaste et al., 2015). Therefore, the Biology learning process should be carried out by providing a learning experience (Çimer, 2012; Fleischner et al., 2017) that is designed to involve the mental and physical processes of students, teachers, learning resources, and media for the achievement of a competency. Choosing the right form of learning will optimize the effort.

One form of learning that can accommodate biology learning optimally is Problem-based Learning (PBL). PBL is included in student-centered oriented learning (Ali, 2019; Karimi, 2011; Qutoshi \& Poudel, 2014). PBL also includes cooperative learning which obeys the theory of constructivism (Gewurtz, Coman, Dhillon, Jung, \& Solomon, 2016). Presentation of problems that must be solved by students is the main characteristic of PBL (Servant-Miklos, 2019). Through this kind of learning scenario, students' cognitive achievement will become more optimal (Aswan, Lufri, \& Sumarmin, 2018; Rotgans \& Schmidt, 2011). In addition to the basic cognitive aspects, students' higher-order thinking skills can also be empowered (Birgili, 2015; Ulger, 2018). Therefore, PBL is included in the form of learning that is most recommended to be applied in this 21st Century era (Phang, Yusof, Aziz, Nawi, \& Musa, 2017; Savin-baden, 2014).

Unfortunately, the textbooks used in various learning in Indonesia are indicated not to be based on the 21 st Century. Empowerment of higher-order thinking skills also seems less facilitated. Furthermore, textbooks still contain a number of weaknesses. Textbooks can not providing authentic listening material (Hanifa, 2018). The textbooks were also poor in language and contains some misconceptions (Ayu, Saputri, \& Widyaningrum, 2016; Novitasari, Ramli, \& Karyanto, 2019). In connection with these indications, content analysis aimed at reviewing biology books used in learning in Indonesia needs to be done.

Various analyzes of book content have actually been carried out. Some of these studies have been carried out in several countries, such as in Turkey (Çobanoğlu \& Şahin, 2009; Çobanoğlu, Şahin, \& Karakaya, 2009) and United States (Chiappetta \& Fillman, 2007). On the other hand, some research in Indonesia has also been carried out. However, textbook content analysis in Indonesia seems to be more frequently done in English textbooks (Gunantar, 2017; Hanifa, 2018; Mayangsari, Nurkamto, \& Supriyadi, 2018). Furthermore, most content analysis conducted in Indonesian biology textbooks is focused on the existence of biological misconceptions (Ayu et al., 2016; Novitasari et al., 2019). In line with those information, research examining the existence of PBL syntax in biology books has never been done. This kind of research needs to be done because it can provide information about how optimal textbooks promote good biology learning. In addition, the findings obtained can be the basis of development research conducted in biology learning. The results can also be used on the basis of the teacher in the selection of student textbooks. Therefore, the purpose of this study was to analyze the existence of PBL syntax in junior high school biology textbooks.

\section{METHOD}

This content analysis research was intended to evaluate the quality of biology textbooks. The evaluation perspective was based on the existence of PBL-oriented learning activities. The research population was all Biology VII grade books spread in the Surakarta region, Indonesia. The research sample was selected through a purposive sampling technique. The sample selection criteria were biology books that are often used by VII grade students in Surakarta. Another criterion was that the book has passed the Indonesian Book Center. From the results of the search, obtained three books used as research samples.

The research procedure begins with the selection of textbooks. After selecting three textbooks, each paragraph in each page of the book was analyzed and matched with the PBL syntax. The fullness of PBL syntax was then calculated and presented. To facilitate the data collection process, observation sheets were used as data collection instruments. The data collection instruments were arranged based on the six PBL syntaxes, namely (1) problem orientation; (2) organizing students to research; (3) assisting independent investigations; (4) artifacts presentation; and (5) analyzing or evaluating the problem-solving process.

In more detail, the data analysis step in this study begins by adding up the value of the appearance of the syntax in the book being analyzed. Next, the percentage of PBL crossing occurrences in each book was calculated. Then the reliability of observations was calculated. Data reliability calculations were based on a 
checklist of two data collectors on data collection instruments. Next, the coefficient of agreement was calculated and the category used to determine the coefficient categories were <0.40: very bad; $0.40-0.75$ : good; and >0.75: very good.

\section{RESULTS AND DISCUSSION}

Evaluation of textbooks is an important step in monitoring the quality of learning. In this study, an evaluation based on the achievement of PBL syntax was carried out on three textbooks circulating in Surakarta. The results of the evaluation are presented in Figure 1. Based on Figure 1, the three books present the entire PBL syntax, from the problem to evaluating the problem-solving process. However, the results of the analysis show that there are no books that have a balanced proportion of syntax. The second syntax, organizing students to research, is the syntax that is most found in all three books. In the syntax of organizing students to research, students are given the opportunity to discuss and share assignments to gather data/materials needed to solve problems. On the other hand, the fourth syntax, artifact presentation, is the syntax that is rarely found in all three books. In the syntax of artifact presentations, students are discussed in their group to produce problem solving solutions whose results are presented. Presentation of results in the form of work. The results of this analysis indicate that the three books are less able to direct students to carry out scientific processes according to PBL.
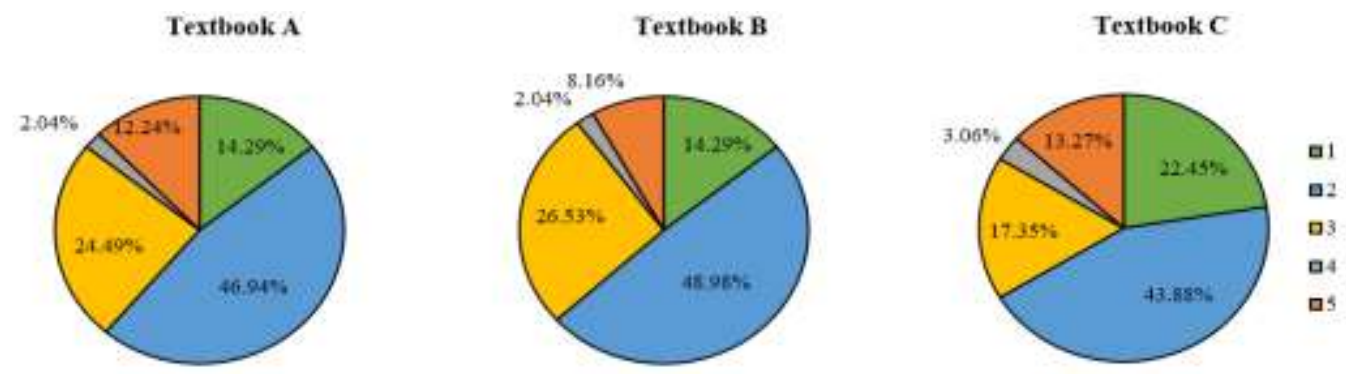

Figure 1. PBL syntax fulfillment percentage in three junior high school biology textbooks. Note: $1=$ problem orientation; $2=$ organizing students to research; $3=$ assisting independent investigation; $4=$ artifacts presentation; $5=$ evaluating the problem-solving process

When referring to the results of the study, biology textbooks in Indonesia are less able to facilitate students in learning nature of science optimally. The poor quality of textbooks has also been reported in previous study that studying different parameter. The results of the study inform that the level of readability of textbooks and the frequency of misconception is very worrying (Nugroho, Vlorensius, Rasidah H., \& Anisa, 2017). Other research also informs that biology textbooks in Indonesia also have a dimension of scientific literacy as the process of investigating in the unfavorable category (Ginting \& Suriani, 2018). These results are in line with other studies conducted in other countries, such as in Thailand (Chaisri \& Thathong, 2014) and Turkey (Çobanoğlu et al., 2009).

The findings obtained reinforce the fact that the textbooks only provide a number of concepts, theories, and even laws without affecting students' higher-order thinking. Many textbooks so far is also too materialistic and do not arouse students' affective awareness. Three books analyzed show that the textbooks has prioritized the product, and put aside the process or attitude. Therefore, the presence of textbooks just facilitated students to memorize variety of concept but have not been able to build their own knowledge or build their own thinking skills. Inadequate and inconsistent scientific knowledge presented in science textbooks can have a negative impact on students' conceptions.

Learning Biology is not just mastering a collection of knowledge in the form of facts, concepts, and principles. In learning Biology, students are also required to carry out the process of finding knowledge (Çimer, 2012; Fleischner et al., 2017; Jiun \& Nurzatulshima, 2014). Because biology is a discipline of science and science is essentially a way or way of thinking, a way of inquiry, a collection of knowledge, which results from human curiosity.

Unfortunately, so far, the development of textbooks that are in accordance with the competencies expected is rarely done by teachers. Accordingly, teachers often use textbooks from publishers, which do not prioritize the existence of models, methods or strategies that support good learning quality. Therefore, the steps in preparing the textbook need to be reviewed. The book is expected to improve the quality of learning, 
one of which is by directing students who read the book to do activities according to PBL syntax. The reason, $\mathrm{PBL}$ is in accordance with the curriculum and new educational paradigm. PBL is able to change the mindset of students, develop the ability to ask questions, and get students involved in group learning. In addition, students are trained to use their thinking skills (Birgili, 2015; Ersoy \& Baser, 2014; Ulger, 2018; Wosinski et al., 2018). Finally, PBL is a form of learning that facilitates students to learn the nature of science (Moutinho, Torres, Fernandes, \& Vasconcelos, 2015).

Based on the findings, other studies aimed at developing PBL-based biology textbooks. The existence of this research is expected to facilitate teachers to provide biology textbooks that are suitable with the characteristics of biology learning. Analysis of the content of biology textbooks from various countries is deemed necessary. Thus, an overview of the quality of books in various countries can be obtained. The information obtained can also be used as a basis for the development of textbooks in Indonesia.

\section{CONCLUSION}

An analysis of the existence of PBL syntax was carried out on three junior biology books. The analysis shows that the five PBL syntaxes appear in each book. However, the proportion between one syntax and the other is not balanced. The syntax organizes students to examine which has the largest proportion, while the syntax presenting the artifact has the smallest proportion. Based on the findings obtained, biology books still do not adequately describe problem-based learning. Regarding from these findings, researchers in biology learning are recommended to conduct development research aimed at developing PBL-based textbooks. This kind of step is important because it can facilitate students learning biology more optimally. In addition, it is also advisable to conduct a content analysis research which involves a larger number of books and a wider circulation area. The results of this study will provide broader conditions regarding the quality of books in circulation in Indonesia.

\section{ACKNOWLEDGMENT}

The Higher Education Collaboration Research Implementation Team of Universitas Muhammadiyah Kupang would like to thank DRPM-Indonesia for providing assistance so that research can be carried out.

\section{REFERENCES}

Ali, S. S. (2019). Problem based learning: A student-centered approach. English Language Teaching, 12(5), 73-78. doi: https://doi.org/10.5539/elt.v12n5p73

Amiryousefi, M., \& Zarei, G. R. (2011). Are MI and motivation catered for in EAP textbooks? Procedia - Social and Behavioral Sciences, 30, 573-577. doi: https://doi.org/10.1016/j.sbspro.2011.10.111

Aswan, D. M., Lufri, L., \& Sumarmin, R. (2018). Influence of problem based learning on Critical Thinking skills and competence class VIII SMPN 1 Gunuang Omeh, 2016/2017. In IOP Conference Series: Materials Science and Engineering (Vol. 335, p. 012128). doi: https://doi.org/10.1088/1757-899X/335/1/012128

Ayu, D., Saputri, F., \& Widyaningrum, T. (2016). Misconceptions analysis on The virus chapter in biology Textbooks for high school students grade X. International Journal of Active Learning, 1(1), 31-37. doi: https://doi.org/10.15294/ijal.v1i1.7781

Behnke, Y. (2018). Textbook effects and efficacy. In The Palgrave Handbook of Textbook Studies (pp. 383398). New York: Palgrave Macmillan US. doi: https://doi.org/10.1057/978-1-137-53142-1_28

Birgili, B. (2015). Creative and critical thinking skills in problem-based learning environments. Journal of Gifted Education and Creativity, 2(2), 71-80. doi: https://doi.org/10.18200/JGEDC.2015214253

Chaisri, A., \& Thathong, K. (2014). The nature of science Represented in Thai biology textbooks under the topic of evolution. In Procedia - Social and Behavioral Sciences (Vol. 116, pp. 621-626). doi: https:/l doi.org/10.1016/j.sbspro.2014.01.268

Chiappetta, E. L., \& Fillman, D. A. (2007). Analysis of five high school biology textbooks used in the United States for inclusion of the nature of science. International Journal of Science Education, 29(15), 18471868. doi: https://doi.org/10.1080/09500690601159407

Çimer, A. (2012). What makes biology learning difficult and effective: Students' views. Educational Research and Reviews, 7(3), 61-71. doi: https://doi.org/10.5897/ERR11.205 
Cimer, A., \& Coskun, S. (2018). Students' opinions about their ninth grade biology textbook: From the perspective of constructivist learning approach. Journal of Education and Learning, 7(4), 201-214. doi: doi: https://doi.org/10.5539/jel.v7n4p201

Çobanoğu, E. O., \& Şahin, B. (2009). Underlining the problems in biology textbook for 10th grades in high school education using the suggestions of practicing teachers. Journal of Turkish Science Education, 6(2), 75-91. Retrieved from https://www.pegem.net/dosyalar/dokuman/124737-2011082717265-8.pdf

Çobanoğlu, E. O., Şahin, B., \& Karakaya, Ç. (2009). Examination of the biology textbook for 10th grades in high school education and the ideas of the pre-service teachers. In Procedia - Social and Behavioral Sciences (Vol. 1, pp. 2504-2512). doi: https://doi.org/10.1016/j.sbspro.2009.01.442

Dolmacl, M., \& Ertal, A. (2016). Developing a textbook-based academic Turkish wordlist. In Procedia - Social and Behavioral Sciences (Vol. 232, pp. 821-827). doi: https://doi.org/10.1016/j.sbspro.2016.10.111

Ersoy, E., \& Baser, N. e. (2014). The effects of problem-based learning method in higher education on creative thinking. Procedia - Social and Behavioral Sciences, 116, 3494-3498. doi: https://doi.org/10. 1016/j.sbspro.2014.01.790

Fleischner, T. L., Espinoza, R. E., Gerrish, G. A., Greene, H. W., Kimmerer, R. W., Lacey, E. A., ... Zander, L. (2017). Teaching biology in the field: Importance, challenges, and solutions. BioScience, 67(6), 558567. doi: https://doi.org/10.1093/biosci/bix036

Gewurtz, R. E., Coman, L., Dhillon, S., Jung, B., \& Solomon, P. (2016). Problem-based learning and theories of teaching and learning in health professional education. Journal of Perspectives in Applied Academic Practice, 4(1), 59-70. doi: https://doi.org/10.14297/jpaap.v4i1.194

Ginting, V. E., \& Suriani, C. (2018). Analisis tingkat literasi sains buku teks biologi kelas XI pada materi sistem saraf di SMA Se- Kecamatan Pancurbatu Tahun Pembelajaran 2016/2017. Jurnal Pelita Pendidikan, 6(1), 7-11. doi: https://doi.org/10.24114/jpp.v6i1.8900

Gu, X., Wu, B., \& Xu, X. (2015). Design, development, and learning in e-Textbooks: What e learned and where we are going. Journal of Computers in Education, 2(1), 25-41. doi: https://doi.org/10.1007/s4069 2-014-0023-9

Gunantar, D. A. (2017). Textbooks analysis: Analyzing English as a Foreign Language (Efl) textbooks from the perspective of Indonesian culture. Language Circle: Journal of Language and Literature, 11(2), 173182. Retrieved from https://journal.unnes.ac.id/nju/index.php/LC/article/download/9590/6204

Ham, A.-K. van den, \& Heinze, A. (2018). Does the textbook matter? Longitudinal effects of textbook choice on primary school students' achievement in mathematics. Studies in Educational Evaluation, 59, 133140. doi: https://doi.org/10.1016/j.stueduc.2018.07.005

Hanifa, R. (2018). EFL published materials: An Evaluation of English textbooks for junior high school in Indonesia. Advances in Language and Literary Studies, 9(2), 166-174. doi: https://doi.org/10.7575/aiac. alls.v.9n.2p.166

Hendikawati, P., \& Arini, F. Y. (2016). The development of statistics textbook supported with ICT and portfoliobased assessment. In Journal of Physics: Conference Series (Vol. 693, p. 012020). doi: https://doi.org/ 10.1088/1742-6596/693/1/012020

Jiun, T., \& Nurzatulshima, K. (2014). Inquiry in learning science. International Journal of Technical Research and Applications, 10, 61-65. Retrieved from https://www.researchgate.net/publication/ 308983046

Karim, S. A. (2015). Developing an Indonesian textbook for non-native learners of Indonesian at elementary. Indonesian Journal of English Language Teaching, 10(2), 52-68. Retrieved from http://ojs.atmajaya. ac.id/index.php/ijelt/article/view/663/522

Karimi, R. (2011). Interface between problem-based learning and a learner-centered paradigm. Advances in Medical Education and Practice, 2, 117. doi: https://doi.org/10.2147/AMEP.S12794

Knight, B. A. (2015). Teachers' use of textbooks in the digital age. Cogent Education, 2(1), 1-10. doi: https://doi.org/10.1080/2331186X.2015.1015812

Lau, K. H., Lam, T., Kam, B. H., Nkhoma, M., Richardson, J., \& Thomas, S. (2018). The role of textbook learning resources in e-learning: A taxonomic study. Computers \& Education, 118, 10-24. doi: https:// doi.org/10.1016/j.compedu.2017.11.005

Mayangsari, L., Nurkamto, J., \& Supriyadi, S. (2018). Cultural Content: An analysis of EFL textbook in Indonesia. International Journal of Scientific and Research Publications (IJSRP), 8(11), 192-199. doi: https://doi.org/10.29322/IJSRP.8.11.2018.p8325

Menkabu, A., \& Harwood, N. (2014). Teachers' conceptualization and use of the textbook on a Medical English Course. In English Language Teaching Textbooks (pp. 145-177). London: Palgrave Macmillan 
UK. doi: https://doi.org/10.1057/9781137276285_5

Mohammadi, M., \& Abdi, H. (2014). Textbook evaluation: A case study. Procedia - Social and Behavioral Sciences, 98, 1148-1155. doi: https://doi.org/10.1016/j.sbspro.2014.03.528

Moutinho, S., Torres, J., Fernandes, I., \& Vasconcelos, C. (2015). Problem-Based Learning and Nature of Science: a study with science teachers. Procedia - Social and Behavioral Sciences, 191, 1871-1875. doi: https://doi.org/10.1016/j.sbspro.2015.04.324

Mukundan, J., Nimehchisalem, V., \& Hajimohammadi, R. (2011). Developing an English language textbook evaluation checklist: A focus group study. International Journal of Humanities and Social Science, 1(12), 100-106. Retrieved from http://www.ijhssnet.com/journals/Vol_1_No_12_September_2011/14.pdf

Novitasari, C., Ramli, M., \& Karyanto, P. (2019). Content analysis of misconceptions on bacteria in the biology textbook of high school. In Journal of Physics: Conference Series (Vol. 1157, p. 022076). doi: https:/l doi.org/10.1088/1742-6596/1157/2/022076

Nugroho, E. D., Vlorensius, V., Rasidah H., L., \& Anisa, N. (2017). Analisis isi, penyakian materi dan keterbacaan dalam buku teks IPA Kurikulum 2013 SMP kelas VII semester 1. JPBI (Jurnal Pendidikan Biologi Indonesia), 3(2), 114-122. doi: https://doi.org/10.22219/jpbi.v3i2.3904

Pedaste, M., Mäeots, M., Siiman, L. A., de Jong, T., van Riesen, S. A. N., Kamp, E. T., ... Tsourlidaki, E. (2015). Phases of inquiry-based learning: Definitions and the inquiry cycle. Educational Research Review, 14, 47-61. doi: https://doi.org/10.1016/j.edurev.2015.02.003

Phang, F. A., Yusof, K. M., Aziz, A. A., Nawi, N. D., \& Musa, A. N. (2017). Cooperative problem-based learning to develop 21st century skills among secondary school students through STEM education. In 7th WEE Forum (pp. 405-409). doi: https://doi.org/10.1109/WEEF.2017.8467 122

Piper, B., Simmons Zuilkowski, S., Dubeck, M., Jepkemei, E., \& King, S. J. (2018). Identifying the essential ingredients to literacy and numeracy improvement: Teacher professional development and coaching, student textbooks, and structured teachers' guides. World Development, 106, 324-336. doi: https://doi.org/10.1016/j.worlddev.2018.01.018

Pop-Pacurar, I., \& Ciascai, L. (2010). Biology school textbooks and their role for students' success in learning sciences. Acta Didactica Napocensia, 3(1), 1-10. Retrieved from https://www.researchgate.net/publica tion/44003831\%0ABiology

Prasetya, S. (2018). The effect of textbooks on learning outcome viewed from different learning motivation. In Proceedings of the 1st International Conference on Education Innovation (ICEI 2017). Paris, France: Atlantis Press. doi: https://doi.org/10.2991/icei-17.2018.83

Qutoshi, S. B., \& Poudel, T. (2014). Student centered approach to teaching: What does it mean for the stakeholders of a community school in Karachi, Pakistan? Journal of Education and Research, 4(1), 2438. doi: https://doi.org/10.3126/jer.v4i1.9620

Rotgans, J.I., \& Schmidt, H.G. (2011). Cognitive engagement in the problem-based learning classroom. Advances in Health Sciences Education, 16(4), 465-479. doi: https://doi.org/10.1007/10459-011-9272-9

Savin-baden, M. (2014). Using problem-based learning: New constellations for the 21st Century. Journal on Excellence in College Teaching, 25, 197-219. Retrieved from http://celt.muohio.edu/ject/fetch.php?id=6

Seftari, V., Milama, B., \& Saridewi, N. (2018). The development of chemistry textbook based on scientific literacy the concept of colloid system (Vol. 115, pp. 208-214). doi: https://doi.org/10.2991/icems-17. 2018.40

Servant-Miklos, V. F. C. (2019). Problem solving skills versus knowledge acquisition: The historical dispute that split problem-based learning into two camps. Advances in Health Sciences Education, 24(3), 619635. doi: https://doi.org/10.1007/s10459-018-9835-0

Simsek, M. R. (2014). Adapting a Turkish middle school textbook to develop cultural awareness. Procedia Social and Behavioral Sciences, 152, 199-204. doi: https://doi.org/10.1016/j.sbspro.2014.09.181

Ulger, K. (2018). The effect of problem-based learning on the creative thinking and critical thinking disposition of students in visual arts education. Interdisciplinary Journal of Problem-Based Learning, 12(1), 1-20. doi: https://doi.org/10.7771/1541-5015.1649

Wen-Cheng, W., Chien-Hung, L., \& Chung-Chieh, L. (2011). Thinking of the textbook in the ESL/EFL classroom. English Language Teaching, 4(2), 91-96. doi: https://doi.org/10.5539/elt.v4n2p91

Wosinski, J., Belcher, A. E., Dürrenberger, Y., Allin, A.-C., Stormacq, C., \& Gerson, L. (2018). Facilitating problem-based learning among undergraduate nursing students: A qualitative systematic review. Nurse Education Today, 60, 67-74. doi: https://doi.org/10.1016/j.nedt.2017.08.015 